\title{
Regulatory $T$ cells and the immune pathogenesis of prenatal infection
}

\author{
Jared H Rowe, James M Ertelt, Lijun Xin and Sing Sing Way \\ Division of Infectious Diseases, Cincinnati Children's Hospital, 3333 Burnet Avenue, MLC 7017, \\ Cincinnati, Ohio 45229, USA \\ Correspondence should be addressed to S S Way; Email: singsing.way@cchmc.org
}

\begin{abstract}
Pregnancy in placental mammals offers exceptional comprehensive benefits of in utero protection, nutrition, and metabolic waste elimination for the developing fetus. However, these benefits also require durable strategies to mitigate maternal rejection of fetal tissues expressing foreign paternal antigens. Since the initial postulate of expanded maternal immune tolerance by Sir Peter Medawar 60 years ago, an amazingly elaborate assortment of molecular and cellular modifications acting both locally at the maternal-placental interface and systemically have been shown to silence potentially detrimental maternal immune responses. In turn, simultaneously maintaining host defense against the infinite array of potential pathogens during pregnancy is equally important. Fortunately, resistance against most infections is preserved seamlessly throughout gestation. On the other hand, recent studies on pathogens with unique predisposition for prenatal infections have uncovered distinctive holes in host defense associated with the reproductive process. Using these infections to probe the response during pregnancy, the immune suppressive regulatory subset of maternal CD4 T cells has been increasingly shown to dictate the inter-workings between prenatal infection susceptibility and pathogenesis of ensuing pregnancy complications. Herein, the recent literature suggesting a necessity for maternal regulatory $T$ cells (Tregs) in pregnancy-induced immunological shifts that sustain fetal tolerance is reviewed. Additional discussion is focused on how expansion of maternal Treg suppression may become exploited by pathogens that cause prenatal infections and the perilous potential of infection-induced immune activation that may mitigate fetal tolerance and inadvertently inject hostility into the protective in utero environment.

Reproduction (2013) 146 R191-R203
\end{abstract}

\section{Introduction}

Pregnancy in eutherian placental mammals requires expanded maternal tolerance to encompass paternal antigens expressed by the developing fetus. This vital process initiated at the earliest stages of pregnancy with the invasion of fetal trophoblast cells into the uterine lining prevents recognition and rejection of foreign fetal cells. Given the essential nature of reproduction for species survival, it is not surprising that numerous nonoverlapping immune evasion strategies that together reinforce protection for the developing fetus have been identified. These include sharply reduced or extinguished expression of immune recognition major histocompatibility $(\mathrm{MHC})$ antigens on trophoblast cells (Sunderland et al. 1981, Ozato et al. 1985, Zuckermann \& Head 1986, Hunt et al. 1987, Mattsson 1998), tryptophan catabolism that prevents maternal T-cell activation (Munn et al. 1998, Mellor \& Munn 2004), selective expression of galectin-1 that moderates T-cell differentiation or Crry that prevents complement deposition (Xu et al. 2000, Blois et al. 2007), entrapment of antigen-presenting cells within the uterus (Collins et al. 2009), and blunted chemokine expression by decidual stromal cells (Nancy et al. 2012). By coalescing these potent immune suppressive features where they are most needed at the maternal-fetal interface, responsiveness that maintains host defense against most pathogens systemically and within non-reproductive tissues would be predicted to be preserved.

On the other hand, since low-level dissemination of fetal cells into maternal blood and non-reproductive tissues also occurs during pregnancy (Liegeois et al. 1981, Guetta et al. 2003, Khosrotehrani et al. 2004), systemic immune modifications may also be needed to reinforce fetal tolerance. Here, multiple nonoverlapping strategies are likely to be simultaneously at work. One is the selective elimination of maternal T cells with high affinity to fetal antigens through apoptotic death in early gestation (Erlebacher et al. 2007). However, this process is incomplete both temporally and for maternal $\mathrm{T}$ cells that recognize fetal antigens with lower affinity, suggesting that other ways to prevent the activation of maternal immune cells with fetal specificity also exist. In this regard, the selective silencing of immune effector cells with specificity to 
non-self paternal antigens during pregnancy can be viewed as an example of peripheral immune tolerance. By contrast, even with substantial overlap between maternal and fetal antigens, central tolerance that eliminates developing T cells with self-specificity within the thymus is less operational since maternal thymectomy does not diminish fertility and, in cases of autoimmunity, may improve the outcomes of pregnancy (Visser et al. 2004, Hoff et al. 2007, Griesemer et al. 2010, Stritesky et al. 2012). Thus, immune components that sustain peripheral tolerance in other contexts (e.g. commensal microbes in tissues with direct contact with the external environment or self-antigens for immune cells that escape central tolerance) are likely to play expanded roles in the maintenance of fetal tolerance during pregnancy. Since the pregnancy-associated immune modifications that sustain fetal tolerance have recently been summarized in a very comprehensive fashion both in general terms and from more distinctive perspectives including the maternal-fetal interface, lymphoid organs that drain this compartment, antigenpresenting dendritic cells, and how immunological shifts affect local susceptibility to viral pathogens (Moffett \& Loke 2006, Bizargity \& Bonney 2009, Mor \& Cardenas 2010, Taglauer et al. 2010, Munoz-Suano et al. 2011, Mold \& McCune 2012, Erlebacher 2013a, 2013b), we use this opportunity to focus more specifically on evidence for systemic immune modifications and how the dynamic cross-regulation between immunological shifts required for sustaining fetal tolerance dictates susceptibility to prenatal infection and the potential immune pathogenesis of ensuing pregnancy complications.

\section{Maternal regulatory $\mathrm{T}$ cells and fetal tolerance}

The FOXP3 ${ }^{+}$subset of CD4 T cells called regulatory T cells (Tregs) has potent immune suppressive properties and plays essential roles in the sustainability of peripheral immune tolerance (Littman \& Rudensky 2010, Wing \& Sakaguchi 2010, Josefowicz et al. 2012). Spontaneous FOXP3 defects result in fatal systemic and organ-specific autoimmunity within the first 6 months of life described as the immune dysregulation, polyendocrinopathy, enteropathy X-linked (IPEX) syndrome (Bennett et al. 2001, Wildin et al. 2001). In turn, similar mortal symptoms arise in mice with naturally occurring or targeted disruptions in Foxp3 (Fontenot et al. 2003, Khattri et al. 2003). The importance of maternal Tregs in fetal tolerance was first suggested by their progressive expansion in healthy human pregnancy and blunted expansion in cases of spontaneous abortion compared with induced abortion (Sasaki et al. 2004, Somerset et al. 2004). At the same time, pioneering studies in mice have shown paralleled levels of maternal Treg accumulation throughout gestation, whereas the selective elimination of maternal
Tregs caused fetal wastage and resorption (Aluvihare et al. 2004).

Within the next few years after these seminal findings, the critical necessity of maternal Tregs in sustaining fetal tolerance has been reinforced by numerous other studies characterizing these cells in human and animal pregnancies. For example, significantly reduced levels of maternal Treg expansion have been reported repeatedly for women with preeclampsia or recurrent spontaneous abortion (Sasaki et al. 2007, Toldi et al. 2008, Yang et al. 2008, Prins et al. 2009, Santner-Nanan et al. 2009, Winger \& Reed 2011). Along with these quantitative reductions, qualitative diminutions in suppressive function among maternal Tregs on a per cell basis have also recently been described for preterm human pregnancies compared with term human pregnancies (Gomez-Lopez \& Laresgoiti-Servitje 2012, Schober et al. 2012). Here, it is important to point out blunted maternal Treg expansion may not be universally associated with all cases of preeclampsia since normal Treg accumulation has also been reported (Paeschke et al. 2005, Hu et al. 2008). However, the interpretation of these isolated negative findings is somewhat moderated by the wide variation in peripheral lymphocyte numbers and Treg percentages among individuals. Nevertheless, consistent reductions in maternal Treg suppression among multiple seemingly unrelated clinical pregnancy complications underscore the potential importance of preserving fetal tolerance by these cells in healthy pregnancy.

The necessity of maternal Tregs in maintaining pregnancy has been more definitively addressed in animal pregnancy models in which experimental manipulation allows the cause and effect relationship of Treg manipulation with regard to pregnancy outcomes to be investigated. During mouse allogeneic pregnancy, maternal Treg depletion or reconstitution of T-celldeficient mice exclusively with non-Treg effector cells each triggers significantly increased rates of fetal resorption with a reciprocal loss of live pups (Aluvihare et al. 2004, Shima et al. 2010, Rowe et al. 2011, Samstein et al. 2012). Furthermore, the accumulation of activated effector $\mathrm{T}$ cells within the decidua and systemic expansion of maternal effector T cells with fetal specificity with ablation of maternal Tregs each reinforce a critical protective role for these cells in sustaining fetal tolerance (Rowe et al. 2011, Samstein et al. 2012). Along with these findings illustrating the necessity for maternal Tregs after the near-complete ablation of these cells, the specific requirement for expanded maternal Foxp3 ${ }^{+}$ cells has also been described. The latter using mice in which the high-affinity human diphtheria toxin receptor is co-expressed with Foxp3 and exploiting the X-linked inheritance of Foxp3 whereby female mice heterozygous for the diphtheria toxin receptor transgene contain an equal ratio of Tregs that are either susceptible or resistant to ablation found that even partial transient ablation to pre-pregnancy levels triggers fetal resorption 
and fractures fetal tolerance (Rowe et al. 2011). Therefore, despite considerable variation in the overall magnitude of fetal resorption between individual studies that probably reflect differences in the timing and efficiency of Treg depletion using unique experimental approaches (Aluvihare et al. 2004, Shima et al. 2010, Rowe et al. 2011, Samstein et al. 2012), these studies in mice collectively illustrate the importance of maternal Tregs and the sustained expansion of these cells in maintaining pregnancy.

Other complementary data highlighting the importance of Tregs in maternal-fetal tolerance are those on evolutionarily conserved genetic elements required for selective FOXP3 expression unique to humans and other eutherian placental mammals that are conspicuously absent in marsupials and egg-laying monotremes (Andersen et al. 2012, Samstein et al. 2012). This includes the Foxp3 enhancer conserved non-coding sequence 1 (CNS1) required for peripheral induced Treg differentiation among non-Treg CD4 T cells (Zheng et al. 2010). Pregnancies in mice with targeted defects in Cns1 show significantly increased rates of fetal resorption with more pronounced decidual inflammation and abnormal spiral artery remodeling consistent with the pathological features of preeclampsia in human pregnancies (Samstein et al. 2012). This apparent requirement for induced Treg differentiation parallels the efficiency whereby trophoblast cells and high-level progesterone each induce FOXP3 expression among non-Treg CD4 T cells (Lee et al. 2012, Ramhorst et al. 2012). On the other hand, using adoptively transferred FOXP3-depleted cells to show that the pre-existing pool of peripheral Foxp3 ${ }^{+}$ CD4 $\mathrm{T}$ cells also contributes significantly to the overall accumulation of maternal Tregs during pregnancy may explain the considerably reduced magnitude of fetal resorption after the selective elimination of induced Tregs based on CNS1 deficiency compared with bulk Tregs based on Foxp3 expression (Rowe et al. 2011, 2012c, Samstein et al. 2012).

Additional investigation exclusive to animal pregnancy has uncovered other interesting facets of the fundamental biology whereby maternal Tregs respond to fetal antigen stimulation. For example, using the wealth of defined inbred strains in mice, maternal Tregs have been shown to accumulate to higher levels during allogeneic pregnancy (when MHC-discordant parents are used for breeding) than during syngeneic pregnancy (between MHC-identical parents) where the only potential source of antigen heterogeneity is that encoded by the $Y$ chromosome (Kahn \& Baltimore 2010, Rowe et al. 2011). Reciprocally, fetal resorption triggered by maternal Treg ablation is consistently reduced in syngeneic pregnancy compared with in allogeneic pregnancy (Aluvihare et al. 2004, Shima et al. 2010, Rowe et al. 2012c, Samstein et al. 2012). Accordingly, the degree of mismatch between maternal and paternal(fetal) MHC alloantigens appears to dictate the necessity for expanded maternal Tregs during pregnancy. In this regard, the natural heterogeneity between maternal and paternal MHC antigens in human pregnancy is more fully recapitulated in mouse allogeneic pregnancy. However, given the selective loss of male offspring with partial ablation of maternal Tregs during syngeneic pregnancy, these cells also probably mitigate mismatch between minor alloantigens encoded on the $\mathrm{Y}$ chromosome (Kahn \& Baltimore 2010). Together, these findings suggest a critical role for the differentiation of maternal Tregs and the sustained expansion of these cells in maintaining tolerance to paternal non-self antigens expressed by the developing fetus during pregnancy.

\section{Pregnancy-induced shifts in systemic immune responsiveness and maternal Tregs}

In addition to these protective roles in the maintenance of fetal tolerance, the sustained accumulation of immune suppressive maternal Tregs has also been linked with notable shifts in non-fetal responses outside female reproductive tissues throughout gestation. A remarkable example of this is the amelioration of many autoimmune disorders during human pregnancy. For example, significant reductions in disease severity or complete remission occur in women with rheumatoid arthritis during pregnancy (Da Silva \& Spector 1992, Barrett et al. 1999, Ostensen \& Villiger 2007, de Man et al. 2009). The protective benefits are most likely conferred by maternal Tregs, given the inverse correlation between disease severity and circulating levels of these cells during pregnancy and after parturition, and the protective capacity of maternal Tregs from mice with pregnancy induced remission from collagen induced arthritis after adoptive transfer into naive recipients (Forger et al. 2008, Munoz-Suano et al. 2012). Similarly for multiple sclerosis, pregnancy-induced amelioration of weakness and clinical disease exacerbations has been reported to be directly associated with the progressive expansion of maternal Tregs (Confavreux et al. 1998, Sanchez-Ramon et al. 2005, lorio et al. 2009). In turn, paralleled disease remission also occurs for Graves' disease and autoimmune hepatitis during pregnancy (Colle \& Hautekeete 1999, Buchel et al. 2002, Weetman 2010). Together, these findings suggest immune tolerance that expands during pregnancy is not restricted only to paternal antigens expressed by the developing fetus, but extends to maternal responsiveness to pathological 'self' antigens that cause autoimmunity as well. Moreover, these unambiguous examples of autoimmunity remission in the joints, thyroid, liver, and central nervous system highlight that although immune modifications at the fetal interface are clearly important for sustaining pregnancy, systemic alterations in immune responsiveness also become engaged during pregnancy. 
With these pregnancy-induced protective benefits that clearly extend beyond fetal tolerance, it may be interesting to consider why the physiological set point for Tregs is not more consistently adjusted to the higher levels found during allogeneic pregnancy. Our recent studies have suggested susceptibility to infection offsets the protective benefits of expanded tolerance from pregnancy-induced maternal Treg accumulation (Rowe et al. 2011). Intriguingly, however, since resistance against most pathogens is not significantly deteriorated with pregnancy, these holes in host defense are probably limited only to those that share the common theme of intracellular survival and placental cell invasion (Robbins \& Bakardjiev 2012). Perhaps the best example of this is the markedly increased susceptibility to disseminated infection with the intracellular bacterium Listeria monocytogenes during human pregnancy that extends to mice and other rodents (Redline \& Lu 1987, 1988, Schuchat et al. 1991, Silver 1998, Bakardjiev et al. 2006, Rowe et al. 2011). Here, pregnancy-induced Treg expansion dictates innate susceptibility because inducing the accumulation of Foxp3 ${ }^{+}$CD4 T cells in non-pregnant mice to levels comparable to that found during allogeneic pregnancy results in paralleled infection susceptibility (Rowe et al. 2011). On the other hand, maternal Treg depletion restores resistance, but at the insufferable cost of fractured fetal tolerance and wastage. Similarly, for Salmonella typhimurium, representing another intracellular bacterium that causes more severe disseminated infection during pregnancy, resistance is restored with maternal Treg ablation (Pejcic-Karapetrovic et al. 2007, Chattopadhyay et al. 2010, Rowe et al. 2011). Thus, susceptibility to a relatively small handful of prenatal pathogens that exploit the physiological hole in host defense created by the reproductive process is probably the unfortunate byproduct of the greater good served by expanded maternal Tregs that sustain fetal tolerance (Fig. 1a).

Another interesting example is the increased susceptibility to influenza A virus during pregnancy. Pregnant women have significantly higher rates of hospitalization, morbidity, and mortality after infection with either pandemic or seasonal influenza A strains (Neuzil et al. 1998, Siston et al. 2010, Pierce et al. 2011). Here, the newly recommended use of inactivated vaccine formulations during pregnancy provides an exceptional opportunity to characterize how pregnancy affects systemic immune responsiveness. Consistent with the notion of systemic immune moderation during pregnancy, reductions in vaccine-induced antibody titers among pregnant women compared with non-pregnant controls with both seasonal and pandemic inactivated influenza A vaccines have been described (Schlaudecker et al. 2012, Bischoff et al. 2013). Similarly, reduced antibody responses have been found among pregnant women after administration of the live attenuated vaccine for yellow fever virus (Nasidi et al. 1993).
However, it is also important to highlight that despite reductions in vaccine-induced influenza A antibody titers during pregnancy, these diminished responses nevertheless provide significant protection for both the mother and infant against respiratory infections, especially in resource-limited environments where influenza A virus is highly endemic (Zaman et al. 2008). These protective benefits of influenza A vaccination during pregnancy for subsequent infection and possibly fetal death have also recently been confirmed in more developed settings where influenza $A$ virus is less prevalent (Haberg et al. 2013). Together, these examples in which immune responsiveness to self-antigens, pathogens, and vaccination each are consistently dampened during pregnancy underscore the exceptional latent systemic immune modulatory properties that become unleashed with gestation. At face value, these findings imply systemic shifts in the balance between immune suppression that averts autoimmunity and immune stimulation required for optimal host defense against infections beyond fetal tolerance become engaged with the accumulation of maternal Tregs during pregnancy.

Along with these quantitative shifts between Tregs and non-Treg effector cells, modifications in Treg suppressive potency on a per cell basis can also occur (Sakaguchi 2003). These qualitative shifts enable Tregs to more efficiently fine-tune the delicate balance between immune activation and suppression by rapidly responding to environmental cues. This feature is probably most critical in the early stages after infection when the race between pathogen replication and immune activation has decisive impacts on the eventual outcome of infection. At the molecular level, this is consistent with drastic shifts in Treg suppressive potency induced by microbial ligands that stimulate cells through conserved pattern recognition receptors such as toll-like receptors. For example, purified lipopolysaccharide (LPS) or flagellin stimulates increased Treg suppressive potency (Caramalho et al. 2003, Crellin et al. 2005), whereas CpG oligonucleotide or the bacterial lipoprotein Pam3Cys-SK4 primes reductions in suppressive potency (Peng et al. 2005, Liu et al. 2006). Importantly, these shifts in Treg suppression after stimulation with individual microbial ligands in vitro parallel similar changes in suppressive potency after in vivo infection with intact pathogens, reflecting the cumulative response to multiple microbial ligands and the ensuing immune responses (Minigo et al. 2009, Johanns et al. 2010, Ertelt et al. 2011).

Applied to the unique physiological situation of pregnancy, in which immune tolerance to fetal antigens must be sustained, fractured tolerance stemming from disruptions in maternal Treg suppression may explain why fetal resorption occurs after systemic LPS administration, especially in mice lacking the immune regulatory cytokine IL10 (Robertson et al. 2006, 2007). Here, a 
Non-pregnant
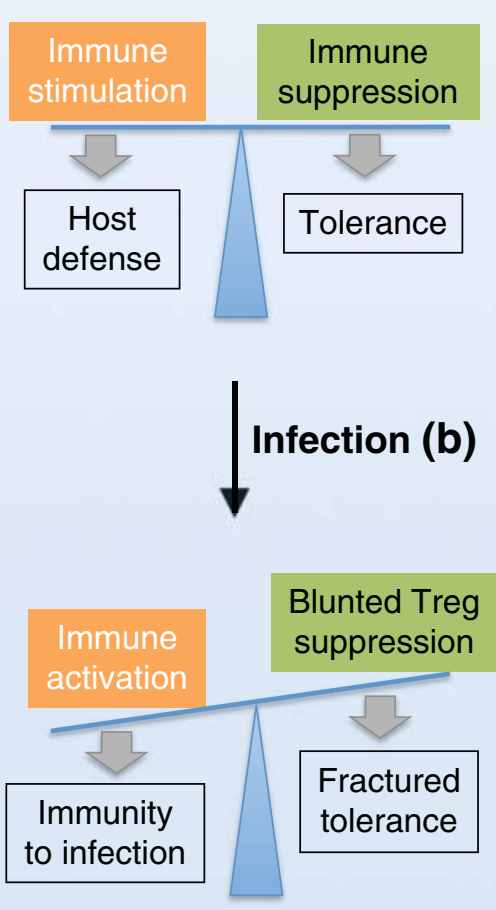

\section{Pregnant}
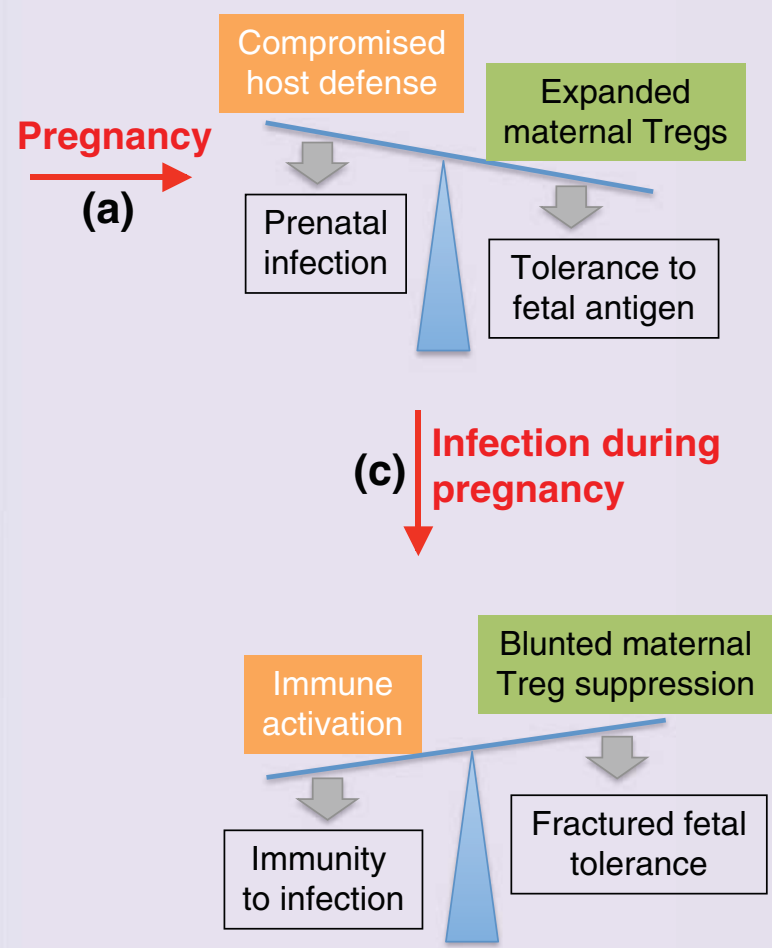

Figure 1 Shifts in the balance between immune stimulation and suppression during pregnancy or following infection may dictate the immune pathogenesis of pregnancy complications after prenatal infection. (a) The expansion of immune suppressive maternal Tregs essential for sustaining fetal tolerance during pregnancy can also compromise host defense against pathogens that cause prenatal infections. (b) Infection- or inflammationinduced reductions in Treg suppression unleash the activation of immune components required for optimal protection against infections.

(c) However, with maternal infection during pregnancy, reductions in Treg suppression that unleash the activation of protective immune components can also fracture fetal tolerance with ensuing immune-mediated pregnancy complications.

specific role for maternal Tregs is supported by the protective properties of purified CD4 $\mathrm{T}$ cells that differentiate into Tregs with LPS-induced preterm delivery (Bizargity et al. 2009). Interestingly, since mice lacking all $\mathrm{T}$ and $\mathrm{B}$ cells $\left(\operatorname{Rag} 1^{-1-}\right)$ are more susceptible to LPS-induced preterm delivery (Bizargity et al. 2009), inflammation-induced activation of innate immune components probably also contributes to pregnancy complications, especially in the absence of Tregs. The extension of Treg suppression in this context is consistent with the increasingly appreciated role that Foxp $3^{+}$cells play in moderating the activation of more prototypical innate immune cells such as neutrophils and natural killer cells (Murphy et al. 2005, D'Alessio et al. 2009, Gasteiger et al. 2013a, 2013b). Thus, dampening maternal Treg suppression that unleashes the activation of innate or adaptive immune response pathways for optimal protection against infections has the potential to unravel the fine-tuned shifted balance between immune suppression and stimulation that maintains fetal tolerance during pregnancy. In this regard, infection-induced disruption of maternal Treg suppression that fractures fetal tolerance may represent an underappreciated, but perhaps more unifying, pathway to explain the fundamental biology whereby pregnancy complications occur with clinically apparent or asymptomatic infections.

\section{Infection-induced shifts in Treg suppression and pregnancy complications}

Although the cause and effect relationships between maternal infection and unfortunate complications in human pregnancy including spontaneous abortion, stillbirth, and preterm labor have been described (Andrews et al. 2000, Goldenberg et al. 2008, McClure et al. 2010), establishing the mechanistic basis whereby maternal infection triggers these complications has lagged behind. One important limitation has been the lack of representative animal models to specifically 
investigate pregnancy outcomes after infection. In particular, while pregnancy outcomes have been extensively characterized using rodent infection models, the discordance in pregnancy kinetics and immune cell development between rodents and humans limits the translational relevance of these findings, especially for complications related to birth timing (Mold \& McCune 2012, Bezold et al. 2013). These limitations are somewhat bypassed in larger mammals including elegant descriptions of pregnancy in horses, sheep, and nonhuman primates (Jobe 2005, Barry et al. 2006, Noronha \& Antczak 2010, Antczak 2012). However, the significantly more prolonged gestation time, relative lack of immunological tools and defined inbred strains, differences in placental architecture, and exponentially higher experimental costs impose other restrictions that are perhaps even more formidable. Furthermore, while human gestational cells and tissues have become more widely used to characterize the pathogenesis of prenatal infections (Robbins et al. 2010, Zeldovich et al. 2011, Robbins et al. 2012), these in vitro models recapitulate neither the dynamic crosstalk between maternal and fetal cells nor the immune response to infections that probably play critical roles in the pathogenesis of pregnancy complications. Therefore, we propose combining the most salient aspects of individual models may represent the most efficient way to uncover the fundamental biology whereby pathogens cause prenatal infection and pregnancy complications.

The additive and potential synergistic value is illustrated by recent complementary studies describing infection and pregnancy outcomes using the intracellular bacterium L. monocytogenes. Using this bacterium to investigate the underlying pathogenesis of prenatal infections is clearly important, given the ubiquitous presence of this pathogen in our food supply, colonization within the gastrointestinal tract, propensity for disseminated infection during pregnancy, and alarming rate of morbidity and mortality associated with human prenatal infection (Gellin \& Broome 1989, MacGowan et al. 1991, Southwick \& Purich 1996, lida et al. 1998, Silver 1998, Mylonakis et al. 2002). A somewhat surprising degree of resistance for placental cells to $L$. monocytogenes infection has been described using human organ cultures (Abrahams et al. 2006, Koga \& Mor 2008, Robbins \& Bakardjiev 2012). In particular, human syncytiotrophoblasts that line the placental surface where nutrient and gas exchange occurs with direct exposure to maternal blood are highly resistant to bacterial invasion and intercellular spread (Robbins et al. 2010). On the other hand, placental invasion primarily occurs through a substantially smaller subset of extravillous trophoblast cells that anchor the placenta in the uterine lining. However, even after invasion into extravillous trophoblast cells, profound defects in L. monocytogenes escape from the endocytic vacuole and intracellular replication remain (Robbins et al.
2012). Interestingly, these protective properties of trophoblasts are not limited to only $L$. monocytogenes, but have also been shown for a variety of other bacterial, parasitic, and viral pathogens (Abrahams et al. 2006, Koga \& Mor 2008, Zeldovich et al. 2011, Robbins \& Bakardjiev 2012). Thus, placental cells provide a protective barrier to fetal infections, at least in vitro without the additional constraints imposed by the ensuing inflammatory response and maternal-fetal tolerance.

In light of these innate cellular barriers to infections, it is interesting to reconsider the basic physiology that causes susceptibility to disseminated infections during pregnancy and the underlying mechanism whereby maternal infection triggers pregnancy complications. With regard to maternal susceptibility to disseminated infections, the prior dogma that placental and fetal tissues represent expanded target tissues susceptible to invasion seems less likely, given the finding that placental cells are actually very resistant to infections (Abrahams et al. 2006, Koga \& Mor 2008, Robbins \& Bakardjiev 2012). Similarly, the notion of pregnancy induced dampening of CD4 helper type 1 (Th1) responses required for protection against intracellular pathogens is questionable, given the unimpeded innate and early adaptive immune responses in MHC class II CD4 T-cell-deficient mice (Sun \& Bevan 2003, Barber et al. 2005). Instead, given the necessity for maintaining fetal tolerance through sustained expansion of immune suppressive maternal Tregs, we propose active suppression by these cells may also play critical roles in causing maternal susceptibility to disseminated infection (Fig. 1a). This notion is supported by the aforementioned epidemiological and experimental data showing increased susceptibility to systemic infections during pregnancy in humans and mice, and non-pregnant mice with expanded Tregs, whereas Treg ablation restores resistance for each group (Redline \& Lu 1987, 1988, Schuchat et al. 1991, Silver 1998, Rowe et al. 2011). Interestingly, however, since immunity against most infections is preserved during pregnancy, these do not appear to be drastic defects in global host defense and are instead more isolated holes that become exploited by pathogens with an established predisposition for infections during pregnancy. Furthermore, given the striking consistency in pathogens that cause prenatal infections in humans and other mammalian species (Givens \& Marley 2008, Robbins \& Bakardjiev 2012), these host defense defects associated with the reproductive process are apparently widely conserved.

Perhaps, more intriguing are the recent findings using allogeneic pregnancy in mice to investigate the pathogenesis of pregnancy complications triggered by disseminated maternal infection. Here, related studies using $L$. monocytogenes as a model to dissect the basic immunology whereby protective T cells are primed after in vivo infection need to be carefully considered in 
parallel. Unlike the necessity for distinct cell-intrinsic stimulation signals including the T-cell receptor (signal 1), co-stimulation (signal 2), and inflammatory cytokines (signal 3) for T-cell activation shown using elegantly simplistic in vitro models (Curtsinger et al. 2005, Curtsinger \& Mescher 2010), CD8 T cells responsive to heterologous antigens expressed by recombinant $L$. monocytogenes expand and become activated even when all known inflammatory cytokine third signals have been eliminated (Way et al. 2007, Orgun et al. 2008, Ertelt et al. 2010). Instead, transient reductions in Treg suppression that unleash the activation of protective immune effector cells following infection probably circumvent the need for some, but not all, more classical T-cell-intrinsic activation signals (Ertelt et al. 2011, 2013). The importance of overriding Treg suppression for immune activation parallels the robust expansion of protective CD8 effector T cells in mice transiently ablated of Tregs after stimulation with purified peptides (Ertelt et al. 2011). Thus, infection- or inflammation-induced reductions in Treg suppression may represent a more fundamental signal zero for stimulating the activation of protective T effector cells (Rowe et al. 2012a; Fig. 1b).

Applied to pregnancy when the sustained expansion of maternal Tregs is essential for maintaining fetal tolerance, infection- or inflammation-induced reductions in Treg suppression have the critical potential to fracture fetal tolerance with ensuing pregnancy complications (Fig. 1c). This has been most definitively shown with a highly informative mating strategy using transgenic male mice that ubiquitously express defined model antigens to establish allogeneic pregnancy with non-transgenic female mice that transform model antigens into surrogate fetal antigens (Erlebacher et al. 2007, Moldenhauer et al. 2009, Taglauer et al. 2009). After L. monocytogenes infection, the normally blunted accumulation of maternal $\mathrm{T}$ effector cells with fetal specificity is overturned (Rowe et al. 2012b). In turn, the robust expansion and activation of maternal T effector cells with fetal specificity with maternal infection recapitulate the quantitative accumulation and qualitative activation of these cells with maternal Treg ablation during pregnancy (Rowe et al. 2011). Intriguingly, although fetal resorption with a reciprocal loss of live pups occurs in a dose-dependent fashion that parallels infection-induced reductions in maternal Treg suppression, bacteria could not be recovered from the majority of resorbed placental-fetal units after infection with low or intermediate dosages of virulent L. monocytogenes (Rowe et al. 2012b). These more recent findings suggesting a threshold inoculum is required for establishing sustained systemic infection are consistent with prior studies illustrating dosedependent rates of placental invasion after i.v. L. monocytogenes inoculation (Redline \& Lu 1987). Here, it is important to highlight that even attenuated
L. monocytogenes that cannot invade the placental-fetal unit due to targeted defects in ActA required for intercellular spread can also induce fetal wastage with disruptions in fetal tolerance and loss of live pups (Bakardjiev et al. 2005, Le Monnier et al. 2007, Rowe et al. 2012b). Thus, L. monocytogenes infection-induced pregnancy complications do not require in utero pathogen invasion and may instead be due to reductions in maternal Treg suppression with ensuing disruptions in fetal tolerance (Fig. 2a).

By showing that pregnancy complications can occur without direct bacterial invasion of the placental-fetal unit, the high frequency of pregnancy complications associated with L. monocytogenes infection during human pregnancy despite placental cell resistance to direct bacterial invasion can be potentially reconciled (Gellin \& Broome 1989, Silver 1998, Mylonakis et al. 2002, Robbins \& Bakardjiev 2012). On the other hand, since a majority of newborn infants are infected when born to mothers with disseminated infection (Mylonakis et al. 2002), there are also presumably ways to bypass the protective placental barrier with infection in vivo. We hypothesize inflammation at the maternal-placental interface induced by disrupted fetal tolerance may provide a more direct conduit drawing circulating bacteria into otherwise resistant placental cells. Thereafter, the previously described local immune suppression at the maternal-placental interface and high bacterial concentrations within the infected placenta probably provide a repository for continuous reinfection (Redline \& Lu 1987, 1988, Bakardjiev et al. 2006). Based on these findings with perinatal L. monocytogenes infection, we propose a model whereby i) the expansion of immune suppressive maternal Tregs required for maintaining fetal tolerance compromises innate protection against disseminated infection, ii) the normally protective blunting of Treg suppression that unleashes the activation of protective immune components to eradicate infection disrupts fetal tolerance with fetal wastage caused by attack from maternal immune cells with infection during pregnancy, and iii) inflammation at the maternal-placental interface with fractured fetal tolerance draws circulating pathogens through the normally protected placental cell barrier promoting fetal invasion (Fig. 2b).

The more general applicability of this model now requires analogous studies with other pathogens that cause prenatal infections and pregnancy complications. In this regard, some clues for pathogens known to cause more severe systemic infections during pregnancy are already in place. For example, S. typhimurium infection during pregnancy triggers catastrophic fetal wastage with exaggerated immune responses within the placenta and approximately twofold reductions in Treg suppressive potency, especially in the later stages of persistent infection (Pejcic-Karapetrovic et al. 2007, Chattopadhyay et al. 2010, Johanns et al. 2010). Similarly, quantitative 
(a)

Low-dosage infection

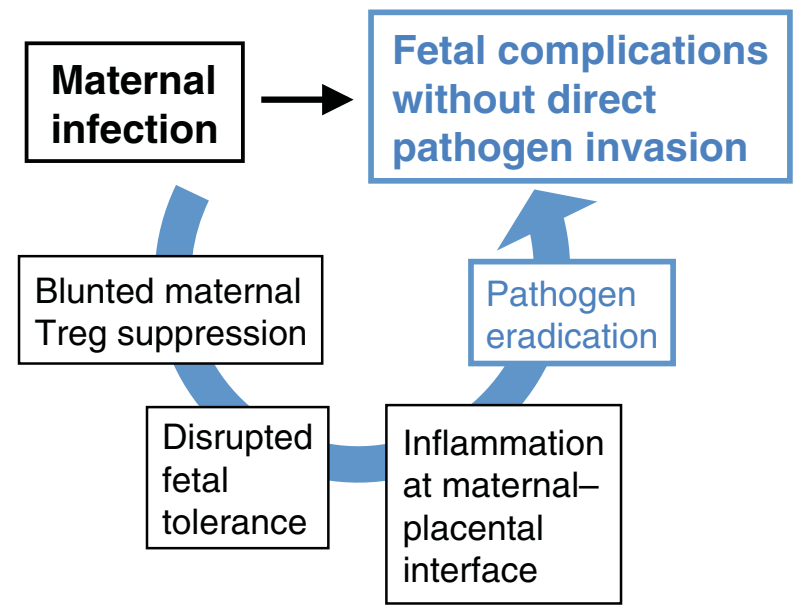

(b)

High-dosage infection

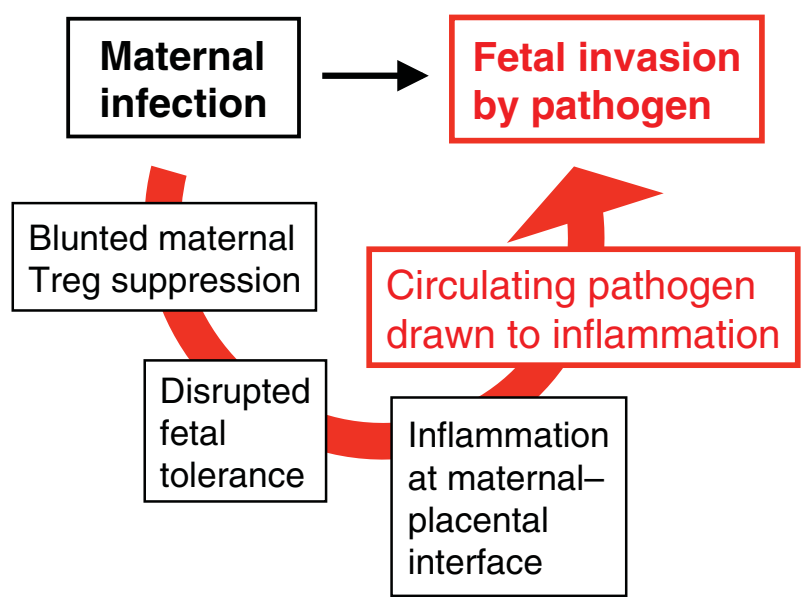

Figure 2 Proposed model for how pregnancy complications may occur with or without direct pathogen invasion of the placental-fetal unit. Infectioninduced reductions in maternal Treg suppression that unleash the activation of protective immune components fracture fetal tolerance unmasking normally tolerized fetal antigens. In turn, inflammation occurs at the maternal-fetal interface containing the highest concentration of exposed fetal cells. With low-dosage infection (a), the circulating pathogen is eradicated, but pregnancy complications ensue from damage caused by the activated maternal immune effector cells. With high-dosage infection (b), the persistence of circulating pathogen and inflammation at the maternal-fetal interface provides a conduit for invasion overriding the normally protective placental barrier.

reductions in peripheral Treg levels have been described in early stages after systemic murine cytomegalovirus and intestinal Toxoplasma gondii infections ( $\mathrm{Li}$ et al. 2008, Oldenhove et al. 2009). If similar reductions in maternal Treg suppression were to occur with infection during pregnancy, disruptions in fetal tolerance with ensuing immune-mediated fetal wastage would be predicted.

It is also important to point out a potentially interesting exception for Plasmodium infection that results in placental localization and robust inflammatory changes leading to intrauterine fetal demise (Poovassery \& Moore 2009, Poovassery et al. 2009). Unlike most other acute infections in which Treg suppression is reduced, increased proportions of activated Tregs with higher suppressive potency are found after Plasmodium infection, and these shifts are likely to minimize inflammatory sequelae at the expense of parasite replication (Walther et al. 2005, Minigo et al. 2009). Therefore, for this infection, other molecules such as chondroitin sulfate providing placental adhesion may provide a more direct conduit for fetal invasion without the need for overturning maternal Treg suppression (Fried \& Duffy 1996, Duffy \& Fried 2003). Nevertheless, given the necessity for sustained maternal Treg expansion in fetal tolerance, infection-induced qualitative or quantitative shifts in Treg suppression highlight a potentially more unifying pathway whereby maternal infection may trigger pregnancy complications.

\section{Summary}

Reproduction and averting infections are arguably the two most dominant fundamental driving forces in nature. Adaptations that simultaneously improve both reproductive fitness and host defense are most ideal and should be strongly enriched for through positive selection. On the other hand, adaptations that favor only one must be counterbalanced by concurrent adaptations that promote or at least sustain the other. With regard to host defense against infections, diversity in immune-recognition MHC molecules between individuals is clearly advantageous for species survival. However, in placental mammals that also require the benefits of more prolonged in utero protection for the fetus, the same antigenic diversity beneficial for host defense is potentially detrimental for reproductive fitness, unless foreign antigens associated with reproduction can be discriminated against those that cause infections. Fortunately, humans and other mammalian species are endowed with many such discriminatory mechanisms that act at the maternal-fetal interface and act more systemically to ensure protection for the developing fetus. Using animal pregnancy models and investigating complications in human pregnancy, we have uncovered some, but certainly not all, the key players in this meticulously orchestrated process.

Based on what we currently know, an elaborate plethora of molecular and cellular changes occurs at the maternal-placental interface to silence local 
activation of potentially detrimental to maternal immune cells. However, these local modifications alone are insufficient as the systemic expansion of immune suppressive maternal regulatory CD4 T cells is also essential. Although Tregs have been shown to impair optimal host defense against a wide variety of potential human pathogens in non-pregnancy models, the expansion of these cells during pregnancy does not lead to increased susceptibility to most. In fact, the detrimental impacts on host defense for expanded maternal Tregs during pregnancy across mammalian species seem to be limited to a remarkably small handful of microbes that share the common features of residence within infected cells and placental colonization. Thus, prenatal pathogens exploit a naturally occurring hole in host defense created by the reproductive process.

As biologists, we can marvel at this apparent intricate regulation that allows protection against the vast array of potential human pathogens and reproduction to occur efficiently enough as we exponentially approach a population of 7 billion individuals. However, as pediatricians and parents, our struggle is to uncover ways to optimize the outcomes of every last pregnancy. It is through the latter perspective that we have focused on why pregnancy leads to susceptibility and the pathogenesis of pregnancy complications after infection with the prototypical prenatal pathogen L. monocytogenes. The most critical data to support increased infection susceptibility during pregnancy and ensuing pregnancy complications associated with maternal Tregs have been discussed. Based on these results, we propose critically important next steps are to investigate whether other microbes that cause prenatal infections either systemically or locally by ascending through the birth canal utilize similar pathogenesis pathways. If so, therapeutic strategies that focus on moderating the immune response to infections, as well as pathogen eradication, may help improve the outcomes of pregnancy. Furthermore, given the remarkable heterogeneity among Tregs in terms of both antigen specificity and cell-intrinsic molecules utilized for suppression, establishing and reinforcing the protective maternal Treg features that sustain pregnancy and dissociating them from others that compromise host defense also represent areas with critical implications for improving maternal and infant health.

\section{Declaration of interest}

The authors declare that there is no conflict of interest that could be perceived as prejudicing the impartiality of the review reported.

\section{Funding}

This work was supported by the NIH-NIAID through awards R01Al100934 and R01Al087830 (S S Way) and training grants from NIH-NIDDK F30DK084674 (J H Rowe). S S Way holds an Investigator in the Pathogenesis of Infectious Disease award from the Burroughs Wellcome Fund.

\section{Acknowledgements}

Given space limitations, the authors apologize for not being able to discuss in a more in-depth fashion or cite the findings from numerous other important prior studies.

\section{References}

Abrahams VM, Schaefer TM, Fahey JV, Visintin I, Wright JA, Aldo PB, Romero R, Wira CR \& Mor G 2006 Expression and secretion of antiviral factors by trophoblast cells following stimulation by the TLR-3 agonist, Poly(I: C). Human Reproduction 21 2432-2439. (doi:10.1093/humrep/ del178)

Aluvihare VR, Kallikourdis M \& Betz AG 2004 Regulatory T cells mediate maternal tolerance to the fetus. Nature Immunology 5 266-271. (doi:10.1038/ni1037)

Andersen KG, Nissen JK \& Betz AG 2012 Comparative genomics reveals key gain-of-function events in Foxp3 during regulatory T cell evolution. Frontiers in Immunology 3 113. (doi:10.3389/fimmu.2012.00113)

Andrews WW, Hauth JC \& Goldenberg RL 2000 Infection and preterm birth. American Journal of Perinatology 17 357-365. (doi:10.1055/ s-2000-13448)

Antczak DF 2012 T-cell tolerance to the developing equine conceptus. Reproduction in Domestic Animals 47 (Suppl 4) 376-383. (doi:10.1111/ j.1439-0531.2012.02101.x)

Bakardjiev Al, Stacy BA \& Portnoy DA 2005 Growth of Listeria monocytogenes in the guinea pig placenta and role of cell-to-cell spread in fetal infection. Journal of Infectious Diseases 191 1889-1897. (doi:10.1086/430090)

Bakardjiev Al, Theriot JA \& Portnoy DA 2006 Listeria monocytogenes traffics from maternal organs to the placenta and back. PLoS Pathogens 2 e66. (doi:10.1371/journal.ppat.0020066)

Barber EM, Fazzari M \& Pollard JW 2005 Th1 cytokines are essential for placental immunity to Listeria monocytogenes. Infection and Immunity 73 6322-6331. (doi:10.1128/IAI.73.10.6322-6331.2005)

Barrett JH, Brennan P, Fiddler M \& Silman AJ 1999 Does rheumatoid arthritis remit during pregnancy and relapse postpartum? Results from a nationwide study in the United Kingdom performed prospectively from late pregnancy Arthritis and Rheumatism 42 1219-1227. (doi:10.1002/ 1529-0131(199906)42:6<1219::AID-ANR19>3.0.CO;2-G)

Barry PA, Lockridge KM, Salamat S, Tinling SP, Yue Y, Zhou SS, Gospe SM Jr, Britt WJ \& Tarantal AF 2006 Nonhuman primate models of intrauterine cytomegalovirus infection. ILAR Journal 47 49-64. (doi:10.1093/ilar.47.1.49)

Bennett CL, Christie J, Ramsdell F, Brunkow ME, Ferguson PJ, Whitesell L, Kelly TE, Saulsbury FT, Chance PF \& Ochs HD 2001 The immune dysregulation, polyendocrinopathy, enteropathy, X-linked syndrome (IPEX) is caused by mutations of FOXP3. Nature Genetics 27 20-21. (doi:10.1038/83713)

Bezold KY, Karjalainen MK, Hallman M, Teramo K \& Muglia LJ 2013 The genomics of preterm birth: from animal models to human studies. Genome Medicine 5 34. (doi:10.1186/gm438)

Bischoff AL, Folsgaard NV, Carson CG, Stokholm J, Pedersen L, Holmberg M, Bisgaard A, Birch S, Tsai TF \& Bisgaard H 2013 Altered response to $\mathrm{A}(\mathrm{H} 1 \mathrm{~N} 1)$ pnd09 vaccination in pregnant women: a single blinded randomized controlled trial. PLOS ONE 8 e56700. (doi:10.1371/ journal.pone.0056700)

Bizargity P \& Bonney EA 2009 Dendritic cells: a family portrait at midgestation. Immunology 126 565-578. (doi:10.1111/j.1365-2567.2008. 02918.x)

Bizargity P, Del Rio R, Phillippe M, Teuscher C \& Bonney EA 2009 Resistance to lipopolysaccharide-induced preterm delivery mediated by regulatory $\mathrm{T}$ cell function in mice. Biology of Reproduction $\mathbf{8 0}$ 874-881. (doi:10.1095/biolreprod.108.074294) 
Blois SM, Ilarregui JM, Tometten M, Garcia M, Orsal AS, Cordo-Russo R, Toscano MA, Bianco GA, Kobelt P, Handjiski B et al. 2007 A pivotal role for galectin-1 in fetomaternal tolerance. Nature Medicine $\mathbf{1 3}$ 1450-1457. (doi:10.1038/nm1680)

Buchel E, Van Steenbergen W, Nevens F \& Fevery J 2002 Improvement of autoimmune hepatitis during pregnancy followed by flare-up after delivery. American Journal of Gastroenterology 97 3160-3165. (doi:10.1111/j.1572-0241.2002.07124.x)

Caramalho I, Lopes-Carvalho T, Ostler D, Zelenay S, Haury M \& Demengeot J 2003 Regulatory T cells selectively express toll-like receptors and are activated by lipopolysaccharide. Journal of Experimental Medicine 197 403-411. (doi:10.1084/jem.20021633)

Chattopadhyay A, Robinson N, Sandhu JK, Finlay BB, Sad S \& Krishnan L 2010 Salmonella enterica serovar Typhimurium-induced placental inflammation and not bacterial burden correlates with pathology and fatal maternal disease. Infection and Immunity 78 2292-2301. (doi:10.1128/IAI.01186-09)

Colle I \& Hautekeete M 1999 Remission of autoimmune hepatitis during pregnancy: a report of two cases. Liver 19 55-57. (doi:10.1111/j.14783231.1999.tb00010.x)

Collins MK, Tay CS \& Erlebacher A 2009 Dendritic cell entrapment within the pregnant uterus inhibits immune surveillance of the maternal/fetal interface in mice. Journal of Clinical Investigation 119 2062-2073.

Confavreux C, Hutchinson $M$, Hours $M M$, Cortinovis-Tourniaire $P$ \& Moreau T 1998 Rate of pregnancy-related relapse in multiple sclerosis. Pregnancy in Multiple Sclerosis Group. New England Journal of Medicine 339 285-291. (doi:10.1056/NEJM199807303390501)

Crellin NK, Garcia RV, Hadisfar O, Allan SE, Steiner TS \& Levings MK 2005 Human CD4+T cells express TLR5 and its ligand flagellin enhances thesuppressive capacity and expression of FOXP3 in CD4+CD25+T regulatory cells. Journal of Immunology 175 8051-8059.

Curtsinger JM \& Mescher MF 2010 Inflammatory cytokines as a third signal for T cell activation. Current Opinion in Immunology 22 333-340. (doi:10.1016/j.coi.2010.02.013)

Curtsinger JM, Valenzuela JO, Agarwal P, Lins D \& Mescher MF 2005 Type I IFNs provide a third signal to CD8 T cells to stimulate clonal expansion and differentiation. Journal of Immunology 174 4465-4469.

D'Alessio FR, Tsushima K, Aggarwal NR, West EE, Willett MH, Britos MF, Pipeling MR, Brower RG, Tuder RM, McDyer JF et al. 2009 CD4+ CD25 + Foxp3 + Tregs resolve experimental lung injury in mice and are present in humans with acute lung injury. Journal of Clinical Investigation 119 2898-2913. (doi:10.1172/JCl36498)

Da Silva JA \& Spector TD 1992 The role of pregnancy in the course and aetiology of rheumatoid arthritis. Clinical Rheumatology 11 189-194. (doi:10.1007/BF02207955)

Duffy PE \& Fried M 2003 Plasmodium falciparum adhesion in the placenta. Current Opinion in Microbiology 6 371-376. (doi:10.1016/S13695274(03)00090-0)

Erlebacher A 2013a Immunology of the maternal-fetal interface. Annual Review of Immunology 31 387-411. (doi:10.1146/annurev-immunol032712-100003)

Erlebacher A 2013b Mechanisms of T cell tolerance towards the allogeneic fetus. Nature Reviews. Immunology 13 23-33. (doi:10.1038/nri3361)

Erlebacher A, Vencato D, Price KA, Zhang D \& Glimcher LH 2007 Constraints in antigen presentation severely restrict $\mathrm{T}$ cell recognition of the allogeneic fetus. Journal of Clinical Investigation 117 1399-1411. (doi:10.1172/JCl28214)

Ertelt JM, Johanns TM, Rowe JH \& Way SS 2010 Interleukin (IL)-21-independent pathogen-specific CD8 + T-cell expansion, and IL-21-dependent suppression of CD4+T-cell IL-17 production. Immunology 131 183-191. (doi:10.1111/j.1365-2567.2010.03287.x)

Ertelt JM, Rowe JH, Mysz MA, Singh C, Roychowdhury M, Aguilera MN \& Way SS 2011 Foxp3 + regulatory T cells impede the priming of protective CD8+T cells. Journal of Immunology 187 2569-2577. (doi:10.4049/ jimmunol.1100374)

Ertelt JM, Buyukbasaran EZ, Jiang TT, Rowe JH, Xin L \& Way SS 2013 B7-1/B7-2 blockade overrides the activation of protective CD8 T cells stimulated in the absence of Foxp3 + regulatory $\mathrm{T}$ cells. Journal of Leukocyte Biology.

Fontenot JD, Gavin MA \& Rudensky AY 2003 Foxp3 programs the development and function of CD4+CD25+ regulatory T cells. Nature Immunology 4 330-336. (doi:10.1038/ni904)
Forger F, Marcoli N, Gadola S, Moller B, Villiger PM \& Ostensen M 2008 Pregnancy induces numerical and functional changes of CD4+ CD25 high regulatory $T$ cells in patients with rheumatoid arthritis. Annals of the Rheumatic Diseases 67 984-990. (doi:10.1136/ard. 2007.075283)

Fried M \& Duffy PE 1996 Adherence of Plasmodium falciparum to chondroitin sulfate A in the human placenta. Science 272 1502-1504. (doi:10.1126/science.272.5267.1502)

Gasteiger G, Hemmers S, Bos PD, Sun JC \& Rudensky AY 2013a IL-2-dependent adaptive control of NK cell homeostasis. Journal of Experimental Medicine 210 1179-1187. (doi:10.1084/jem.20122571)

Gasteiger G, Hemmers S, Firth MA, Le Floc'h A, Huse M, Sun JC \& Rudensky AY 2013b IL-2-dependent tuning of NK cell sensitivity for target cells is controlled by regulatory T cells. Journal of Experimental Medicine 210 1167-1178. (doi:10.1084/jem.20122462)

Gellin BG \& Broome CV 1989 Listeriosis. Journal of the American Medical Association 261 1313-1320. (doi:10.1001/jama.1989.034200 90077035)

Givens MD \& Marley MS 2008 Infectious causes of embryonic and fetal mortality. Theriogenology 70 270-285. (doi:10.1016/j.theriogenology. 2008.04.018)

Goldenberg RL, Culhane JF, lams JD \& Romero R 2008 Epidemiology and causes of preterm birth. Lancet 371 75-84. (doi:10.1016/S01406736(08)60074-4)

Gomez-Lopez N \& Laresgoiti-Servitje E 2012 T regulatory cells: regulating both term and preterm labor? Immunology and Cell Biology 90 919-920. (doi:10.1038/icb.2012.48)

Griesemer AD, Sorenson EC \& Hardy MA 2010 The role of the thymus in tolerance. Transplantation 90 465-474. (doi:10.1097/TP.0b013e3181e 7e54f)

Guetta E, Gordon D, Simchen MJ, Goldman B \& Barkai G 2003 Hematopoietic progenitor cells as targets for non-invasive prenatal diagnosis: detection of fetal CD34+ cells and assessment of postdelivery persistence in the maternal circulation. Blood Cells, Molecules \& Diseases 30 13-21. (doi:10.1016/S1079-9796(03)00008-1)

Haberg SE, Trogstad L, Gunnes N, Wilcox AJ, Gjessing HK, Samuelsen SO, Skrondal A, Cappelen I, Engeland A, Aavitsland P et al. 2013 Risk of fetal death after pandemic influenza virus infection or vaccination. New England Journal of Medicine 368 333-340. (doi:10.1056/NEJM oa1207210)

Hoff JM, Daltveit AK \& Gilhus NE 2007 Myasthenia gravis in pregnancy and birth: identifying risk factors, optimising care. European Journal of Neurology 14 38-43. (doi:10.1111/j.1468-1331.2006.01538.x)

Hu D, Chen Y, Zhang W, Wang H, Wang Z \& Dong M 2008 Alteration of peripheral CD4+CD25+ regulatory T lymphocytes in pregnancy and pre-eclampsia. Acta Obstetricia et Gynecologica Scandinavica 87 190-194. (doi:10.1080/00016340701823991)

Hunt JS, Andrews GK \& Wood GW 1987 Normal trophoblasts resist induction of class I HLA. Journal of Immunology 138 2481-2487.

lida T, Kanzaki M, Nakama A, Kokubo Y, Maruyama T \& Kaneuchi C 1998 Detection of Listeria monocytogenes in humans, animals and foods. Journal of Veterinary Medical Science 60 1341-1343. (doi:10.1292/ jvms.60.1341)

Iorio R, Frisullo G, Nociti V, Patanella KA, Bianco A, Marti A, Mirabella M, Tonali PA \& Batocchi AP 2009 T-bet, pSTAT1 and pSTAT3 expression in peripheral blood mononuclear cells during pregnancy correlates with post-partum activation of multiple sclerosis. Clinical Immunology 131 70-83. (doi:10.1016/j.clim.2008.10.013)

Jobe AH 2005 Antenatal associations with lung maturation and infection. Journal of Perinatology 25 (Suppl 2) S31-S35. (doi:10.1038/sj.jp. 7211317)

Johanns TM, Ertelt JM, Rowe JH \& Way SS 2010 Regulatory T cell suppressive potency dictates the balance between bacterial proliferation and clearance during persistent Salmonella infection. PLoS Pathogens 6 e1001043. (doi:10.1371/journal.ppat.1001043)

Josefowicz SZ, Lu LF \& Rudensky AY 2012 Regulatory T cells: mechanisms of differentiation and function. Annual Review of Immunology 30 531-564. (doi:10.1146/annurev.immunol.25.022106.141623)

Kahn DA \& Baltimore D 2010 Pregnancy induces a fetal antigen-specific maternal T regulatory cell response that contributes to tolerance. PNAS 107 9299-9304. (doi:10.1073/pnas.1003909107) 
Khattri R, Cox T, Yasayko SA \& Ramsdell F 2003 An essential role for Scurfin in CD4 + CD25 + T regulatory cells. Nature Immunology 4 337-342. (doi:10.1038/ni909)

Khosrotehrani K, Johnson KL, Cha DH, Salomon RN \& Bianchi DW 2004 Transfer of fetal cells with multilineage potential to maternal tissue. Journal of the American Medical Association 292 75-80. (doi:10.1001/ jama.292.1.75)

Koga K \& Mor G 2008 Expression and function of toll-like receptors at the maternal-fetal interface. Reproductive Sciences 15 231-242. (doi:10.1177/1933719108316391)

Lee JH, Lydon JP \& Kim CH 2012 Progesterone suppresses the mTOR pathway and promotes generation of induced regulatory $\mathrm{T}$ cells with increased stability. European Journal of Immunology 42 2683-2696. (doi:10.1002/eji.201142317)

Le Monnier A, Autret N, Join-Lambert OF, Jaubert F, Charbit A, Berche P \& Kayal S 2007 ActA is required for crossing of the fetoplacental barrier by Listeria monocytogenes. Infection and Immunity 75 950-957. (doi:10.1128/IAI.01570-06)

Li YN, Zhou YF, Shu SN, Zhu DD, Yang ZF \& Fang F 2008 Effects of acute and chronic murine cytomegalovirus infections on the ratio of regulatory T cells and expression of Th1/Th2 transcription factors T-bet/GATA-3. Zhonghua Yi Xue Za Zhi 88 2999-3002.

Liegeois A, Gaillard MC, Ouvre E \& Lewin D 1981 Microchimerism in pregnant mice. Transplantation Proceedings 13 1250-1252.

Littman DR \& Rudensky AY 2010 Th17 and regulatory T cells in mediating and restraining inflammation. Cell 140 845-858. (doi:10.1016/j.cell. 2010.02.021)

Liu H, Komai-Koma M, Xu D \& Liew FY 2006 Toll-like receptor 2 signaling modulates the functions of CD4 + CD25 + regulatory T cells. PNAS 103 7048-7053. (doi:10.1073/pnas.0601554103)

MacGowan AP, Marshall RJ, MacKay IM \& Reeves DS 1991 Listeria faecal carriage by renal transplant recipients, haemodialysis patients and patients in general practice: its relation to season, drug therapy, foreign travel, animal exposure and diet. Epidemiology and Infection 106 157-166. (doi:10.1017/S0950268800056521)

de Man YA, Hazes JM, van der Heide H, Willemsen SP, de Groot CJ, Steegers EA \& Dolhain RJ 2009 Association of higher rheumatoid arthritis disease activity during pregnancy with lower birth weight: results of a national prospective study. Arthritis and Rheumatism 60 3196-3206. (doi:10.1002/art.24914)

Mattsson R 1998 The non-expression of MHC class II in trophoblast cells. American Journal of Reproductive Immunology 40 383-384.

McClure EM, Dudley DJ, Reddy UM \& Goldenberg RL 2010 Infectious causes of stillbirth: a clinical perspective. Clinical Obstetrics and Gynecology 53 635-645. (doi:10.1097/GRF.0b013e3181eb6620)

Mellor AL \& Munn DH 2004 IDO expression by dendritic cells: tolerance and tryptophan catabolism. Nature Reviews. Immunology 4 762-774. (doi:10.1038/nri1457)

Minigo G, Woodberry T, Piera KA, Salwati E, Tjitra E, Kenangalem E, Price RN, Engwerda CR, Anstey NM \& Plebanski M 2009 Parasitedependent expansion of TNF receptor II-positive regulatory T cells with enhanced suppressive activity in adults with severe malaria. PLoS Pathogens 5 e1000402. (doi:10.1371/journal.ppat.1000402)

Moffett A \& Loke C 2006 Immunology of placentation in eutherian mammals. Nature Reviews. Immunology 6 584-594. (doi:10.1038/nri1897)

Mold JE \& McCune JM 2012 Immunological tolerance during fetal development: from mouse to man. Advances in Immunology 115 73-111.

Moldenhauer LM, Diener KR, Thring DM, Brown MP, Hayball JD \& Robertson SA 2009 Cross-presentation of male seminal fluid antigens elicits $\mathrm{T}$ cell activation to initiate the female immune response to pregnancy. Journal of Immunology 182 8080-8093. (doi:10.4049/ jimmunol.0804018)

Mor G \& Cardenas I 2010 The immune system in pregnancy: a unique complexity. American Journal of Reproductive Immunology 63 425-433. (doi:10.1111/j.1600-0897.2010.00836.x)

Munn DH, Zhou M, Attwood JT, Bondarev I, Conway SJ, Marshall B, Brown C \& Mellor AL 1998 Prevention of allogeneic fetal rejection by tryptophan catabolism. Science 281 1191-1193. (doi:10.1126/science. 281.5380.1191)
Munoz-Suano A, Hamilton AB \& Betz AG 2011 Gimme shelter: the immune system during pregnancy. Immunological Reviews 241 20-38. (doi:10.1111/j.1600-065X.2011.01002.x)

Munoz-Suano A, Kallikourdis M, Sarris M \& Betz AG 2012 Regulatory $\mathrm{T}$ cells protect from autoimmune arthritis during pregnancy. Journal of Autoimmunity 38 J103-J108. (doi:10.1016/j.jaut.2011.09.007)

Murphy TJ, Ni Choileain N, Zang Y, Mannick JA \& Lederer JA 2005 CD4+ $\mathrm{CD} 25+$ regulatory $\mathrm{T}$ cells control innate immune reactivity after injury. Journal of Immunology 174 2957-2963.

Mylonakis E, Paliou M, Hohmann EL, Calderwood SB \& Wing EJ 2002 Listeriosis during pregnancy: a case series and review of 222 cases. Medicine 81 260-269. (doi:10.1097/00005792-200207000-00002)

Nancy P, Tagliani E, Tay CS, Asp P, Levy DE \& Erlebacher A 2012 Chemokine gene silencing in decidual stromal cells limits $T$ cell access to the maternal-fetal interface. Science 336 1317-1321. (doi:10.1126/ science.1220030)

Nasidi A, Monath TP, Vandenberg J, Tomori O, Calisher $\mathrm{CH}$, Hurtgen X, Munube GR, Sorungbe AO, Okafor GC \& Wali S 1993 Yellow fever vaccination and pregnancy: a four-year prospective study. Transactions of the Royal Society of Tropical Medicine and Hygiene 87 337-339. (doi:10.1016/0035-9203(93)90156-K)

Neuzil KM, Reed GW, Mitchel EF, Simonsen L \& Griffin MR 1998 Impact of influenza on acute cardiopulmonary hospitalizations in pregnant women. American Journal of Epidemiology 148 1094-1102. (doi:10.1093/oxfordjournals.aje.a009587)

Noronha LE \& Antczak DF 2010 Maternal immune responses to trophoblast: the contribution of the horse to pregnancy immunology. American Journal of Reproductive Immunology 64 231-244. (doi:10.1111/j.1600-0897.2010.00895.x)

Oldenhove G, Bouladoux N, Wohlfert EA, Hall JA, Chou D, Dos Santos L, O'Brien S, Blank R, Lamb E, Natarajan S et al. 2009 Decrease of Foxp3 + Treg cell number and acquisition of effector cell phenotype during lethal infection. Immunity 31 772-786. (doi:10.1016/j.immuni. 2009.10.001)

Orgun NN, Mathis MA, Wilson CB \& Way SS 2008 Deviation from a strong Th1-dominated to a modest Th17-dominated CD4 T cell response in the absence of IL-12p40 and type I IFNs sustains protective CD8 T cells. Journal of Immunology 180 4109-4115.

Ostensen M \& Villiger PM 2007 The remission of rheumatoid arthritis during pregnancy. Seminars in Immunopathology 29 185-191. (doi:10.1007/s00281-007-0072-5)

Ozato K, Wan YJ \& Orrison BM 1985 Mouse major histocompatibility class I gene expression begins at midsomite stage and is inducible in earlier-stage embryos by interferon. PNAS 82 2427-2431. (doi:10.1073/ pnas.82.8.2427)

Paeschke S, Chen F, Horn N, Fotopoulou C, Zambon-Bertoja A, Sollwedel A, Zenclussen ML, Casalis PA, Dudenhausen JW, Volk HD et al. 2005 Pre-eclampsia is not associated with changes in the levels of regulatory $\mathrm{T}$ cells in peripheral blood. American Journal of Reproductive Immunology 54 384-389. (doi:10.1111/j.1600-0897.2005.00334.x)

Pejcic-Karapetrovic B, Gurnani K, Russell MS, Finlay BB, Sad S \& Krishnan L 2007 Pregnancy impairs the innate immune resistance to Salmonella typhimurium leading to rapid fatal infection. Journal of Immunology 179 6088-6096.

Peng G, Guo Z, Kiniwa Y, Voo KS, Peng W, Fu T, Wang DY, Li Y, Wang HY \& Wang RF 2005 Toll-like receptor 8-mediated reversal of CD4+ regulatory $\mathrm{T}$ cell function. Science 309 1380-1384. (doi:10.1126/ science.1113401)

Pierce M, Kurinczuk JJ, Spark P, Brocklehurst P \& Knight M 2011 Perinatal outcomes after maternal 2009/H1N1 infection: national cohort study. BMJ 342 d3214. (doi:10.1136/bmj.d3214)

Poovassery J \& Moore JM 2009 Association of malaria-induced murine pregnancy failure with robust peripheral and placental cytokine responses. Infection and Immunity 77 4998-5006. (doi:10.1128/IAI. 00617-09)

Poovassery JS, Sarr D, Smith G, Nagy T \& Moore JM 2009 Malaria-induced murine pregnancy failure: distinct roles for IFN- $\gamma$ and TNF. Journal of Immunology 183 5342-5349. (doi:10.4049/jimmunol.0901669)

Prins JR, Boelens HM, Heimweg J, Van der Heide S, Dubois AE, Van Oosterhout AJ \& Erwich JJ 2009 Preeclampsia is associated 
with lower percentages of regulatory $\mathrm{T}$ cells in maternal blood. Hypertension in Pregnancy 28 300-311. (doi:10.1080/106419508026 01237)

Ramhorst R, Fraccaroli L, Aldo P, Alvero AB, Cardenas I, Leiros CP \& Mor G 2012 Modulation and recruitment of inducible regulatory T cells by first trimester trophoblast cells. American Journal of Reproductive Immunology 67 17-27. (doi:10.1111/j.1600-0897.2011.01056.x)

Redline RW \& Lu CY 1987 Role of local immunosuppression in murine fetoplacental listeriosis. Journal of Clinical Investigation 79 1234-1241. (doi:10.1172/JCI112942)

Redline RW \& Lu CY 1988 Specific defects in the anti-listerial immune response in discrete regions of the murine uterus and placenta account for susceptibility to infection. Journal of Immunology 140 3947-3955.

Robbins JR \& Bakardjiev Al 2012 Pathogens and the placental fortress. Current Opinion in Microbiology 15 36-43. (doi:10.1016/j.mib.2011. 11.006)

Robbins JR, Skrzypczynska KM, Zeldovich VB, Kapidzic M \& Bakardjiev AI 2010 Placental syncytiotrophoblast constitutes a major barrier to vertical transmission of Listeria monocytogenes. PLoS Pathogens 6 e1000732. (doi:10.1371/journal.ppat.1000732)

Robbins JR, Zeldovich VB, Poukchanski A, Boothroyd JC \& Bakardjiev AI 2012 Tissue barriers of the human placenta to infection with Toxoplasma gondii. Infection and Immunity 80 418-428. (doi:10.1128/IAI. 05899-11)

Robertson SA, Skinner RJ \& Care AS 2006 Essential role for IL-10 in resistance to lipopolysaccharide-induced preterm labor in mice. Journal of Immunology 177 4888-4896.

Robertson SA, Care AS \& Skinner RJ 2007 Interleukin 10 regulates inflammatory cytokine synthesis to protect against lipopolysaccharideinduced abortion and fetal growth restriction in mice. Biology of Reproduction 76 738-748. (doi:10.1095/biolreprod.106.056143)

Rowe JH, Ertelt JM, Aguilera MN, Farrar MA \& Way SS 2011 Foxp3(+) regulatory $\mathrm{T}$ cell expansion required for sustaining pregnancy compromises host defense against prenatal bacterial pathogens. Cell Host \& Microbe 10 54-64. (doi:10.1016/j.chom.2011.06.005)

Rowe JH, Ertelt JM \& Way SS 2012a Foxp3(+) regulatory T cells, immune stimulation and host defence against infection. Immunology 136 1-10. (doi:10.1111/j.1365-2567.2011.03551.x)

Rowe JH, Ertelt JM, Xin L \& Way SS 2012b Listeria monocytogenes cytoplasmic entry induces fetal wastage by disrupting maternal Foxp3(+) regulatory T cell-sustained fetal tolerance. PLoS Pathogens 8 e1002873. (doi:10.1371/journal.ppat.1002873)

Rowe JH, Ertelt JM, Xin L \& Way SS 2012c Pregnancy imprints regulatory memory that sustains anergy to fetal antigen. Nature 490 102-106. (doi:10.1038/nature11462)

Sakaguchi S 2003 Control of immune responses by naturally arising CD4+ regulatory T cells that express toll-like receptors. Journal of Experimental Medicine 197 397-401. (doi:10.1084/jem.20030012)

Samstein RM, Josefowicz SZ, Arvey A, Treuting PM \& Rudensky AY 2012 Extrathymic generation of regulatory $T$ cells in placental mammals mitigates maternal-fetal conflict. Cell 150 29-38. (doi:10.1016/j.cell. 2012.05.031)

Sanchez-Ramon S, Navarro AJ, Aristimuno C, Rodriguez-Mahou M, Bellon JM, Fernandez-Cruz E \& de Andres C 2005 Pregnancy-induced expansion of regulatory T-lymphocytes may mediate protection to multiple sclerosis activity. Immunology Letters 96 195-201. (doi:10.1016/j.imlet. 2004.09.004)

Santner-Nanan B, Peek MJ, Khanam R, Richarts L, Zhu E, Fazekas de St Groth B \& Nanan R 2009 Systemic increase in the ratio between Foxp3 + and IL-17-producing CD4 $+\mathrm{T}$ cells in healthy pregnancy but not in preeclampsia. Journal of Immunology $\mathbf{1 8 3}$ 7023-7030. (doi:10.4049/jimmunol.0901154)

Sasaki Y, Sakai M, Miyazaki S, Higuma S, Shiozaki A \& Saito S 2004 Decidual and peripheral blood CD4 + CD25 + regulatory T cells in early pregnancy subjects and spontaneous abortion cases. Molecular Human Reproduction 10 347-353. (doi:10.1093/molehr/gah044)

Sasaki Y, Darmochwal-Kolarz D, Suzuki D, Sakai M, Ito M, Shima T, Shiozaki A, Rolinski J \& Saito S 2007 Proportion of peripheral blood and decidual $\mathrm{CD} 4(+) \mathrm{CD} 25$ (bright) regulatory $\mathrm{T}$ cells in pre-eclampsia. Clinical and Experimental Immunology 149 139-145. (doi:10.1111/ j.1365-2249.2007.03397.x)
Schlaudecker EP, McNeal MM, Dodd CN, Ranz JB \& Steinhoff MC 2012 Pregnancy modifies the antibody response to trivalent influenza immunization. Journal of Infectious Diseases 206 1670-1673. (doi:10.1093/ infdis/jis592)

Schober L, Radnai D, Schmitt E, Mahnke K, Sohn C \& Steinborn A 2012 Term and preterm labor: decreased suppressive activity and changes in composition of the regulatory T-cell pool. Immunology and Cell Biology 90 935-944. (doi:10.1038/icb.2012.33)

Schuchat A, Swaminathan B \& Broome CV 1991 Epidemiology of human listeriosis. Clinical Microbiology Reviews 4 169-183.

Shima T, Sasaki Y, Itoh M, Nakashima A, Ishii N, Sugamura K \& Saito S 2010 Regulatory T cells are necessary for implantation and maintenance of early pregnancy but not late pregnancy in allogeneic mice. Journal of Reproductive Immunology 85 121-129. (doi:10.1016/j.jri. 2010.02.006)

Silver HM 1998 Listeriosis during pregnancy. Obstetrical \& Gynecological Survey 53 737-740. (doi:10.1097/00006254-199812000-00004)

Siston AM, Rasmussen SA, Honein MA, Fry AM, Seib K, Callaghan WM, Louie J, Doyle TJ, Crockett M, Lynfield R et al. 2010 Pandemic 2009 influenza $\mathrm{A}(\mathrm{H} 1 \mathrm{~N} 1)$ virus illness among pregnant women in the United States. Journal of the American Medical Association 303 1517-1525. (doi:10.1001/jama.2010.479)

Somerset DA, Zheng Y, Kilby MD, Sansom DM \& Drayson MT 2004 Normal human pregnancy is associated with an elevation in the immune suppressive CD25 + CD4 + regulatory T-cell subset. Immunology 112 38-43. (doi:10.1111/j.1365-2567.2004.01869.x)

Southwick FS \& Purich DL 1996 Intracellular pathogenesis of listeriosis. New England Journal of Medicine 334 770-776. (doi:10.1056/NEJM 199603213341206)

Stritesky GL, Jameson SC \& Hogquist KA 2012 Selection of self-reactive T cells in the thymus. Annual Review of Immunology 30 95-114. (doi:10.1146/annurev-immunol-020711-075035)

Sun JC \& Bevan MJ 2003 Defective CD8 T cell memory following acute infection without CD4 T cell help. Science 300 339-342. (doi:10.1126/ science.1083317)

Sunderland CA, Naiem M, Mason DY, Redman CW \& Stirrat GM 1981 The expression of major histocompatibility antigens by human chorionic villi. Journal of Reproductive Immunology 3 323-331. (doi:10.1016/01650378(81)90048-6)

Taglauer ES, Yankee TM \& Petroff MG 2009 Maternal PD-1 regulates accumulation of fetal antigen-specific CD8 $+\mathrm{T}$ cells in pregnancy. Journal of Reproductive Immunology 80 12-21. (doi:10.1016/j.jri. 2008.12.001)

Taglauer ES, Adams Waldorf KM \& Petroff MG 2010 The hidden maternalfetal interface: events involving the lymphoid organs in maternal-fetal tolerance. International Journal of Developmental Biology 54 421-430. (doi:10.1387/ijdb.082800et)

Toldi G, Svec P, Vasarhelyi B, Meszaros G, Rigo J, Tulassay T \& Treszl A 2008 Decreased number of FoxP3 + regulatory T cells in preeclampsia. Acta Obstetricia et Gynecologica Scandinavica 87 1229-1233. (doi:10.1080/00016340802389470)

Visser J, Klatter F, Hillebrands JL, Jansen A, Vijfschaft L \& Rozing J 2004 Thymectomy should be the first choice in the protection of diabetesprone BB rats for breeding purposes. Laboratory Animals 38 371-375. (doi:10.1258/0023677041958936)

Walther $M$, Tongren JE, Andrews L, Korbel D, King E, Fletcher $H$, Andersen RF, Bejon P, Thompson F, Dunachie SJ et al. 2005 Upregulation of TGF- $\beta$, FOXP3, and CD $4+$ CD $25+$ regulatory T cells correlates with more rapid parasite growth in human malaria infection. Immunity 23 287-296. (doi:10.1016/j.immuni.2005.08.006)

Way SS, Havenar-Daughton C, Kolumam GA, Orgun NN \& Murali-Krishna K 2007 IL-12 and type-I IFN synergize for IFN- $\gamma$ production by CD4 $\mathrm{T}$ cells, whereas neither are required for IFN- $\gamma$ production by CD8 $\mathrm{T}$ cells after Listeria monocytogenes infection. Journal of Immunology 178 4498-4505.

Weetman AP 2010 Immunity, thyroid function and pregnancy: molecular mechanisms. Nature Reviews. Endocrinology 6 311-318. (doi:10.1038/ nrendo.2010.46)

Wildin RS, Ramsdell F, Peake J, Faravelli F, Casanova JL, Buist N, Levy-Lahad E, Mazzella M, Goulet O, Perroni L et al. 2001 X-linked 
neonatal diabetes mellitus, enteropathy and endocrinopathy syndrome is the human equivalent of mouse scurfy. Nature Genetics 27 18-20. (doi:10.1038/83707)

Wing K \& Sakaguchi S 2010 Regulatory T cells exert checks and balances on self tolerance and autoimmunity. Nature Immunology 11 7-13. (doi:10.1038/ni.1818)

Winger EE \& Reed JL 2011 Low circulating CD4(+) CD25(+) Foxp3(+) $\mathrm{T}$ regulatory cell levels predict miscarriage risk in newly pregnant women with a history of failure. American Journal of Reproductive Immunology 66 320-328. (doi:10.1111/j.1600-0897.2011.00992.x)

Xu C, Mao D, Holers VM, Palanca B, Cheng AM \& Molina H 2000 A critical role for murine complement regulator Crry in fetomaternal tolerance. Science 287 498-501. (doi:10.1126/science.287.5452.498)

Yang H, Qiu L, Chen G, Ye Z, Lu C \& Lin Q 2008 Proportional change of $\mathrm{CD} 4+\mathrm{CD} 25+$ regulatory $\mathrm{T}$ cells in decidua and peripheral blood in unexplained recurrent spontaneous abortion patients. Fertility and Sterility 89 656-661. (doi:10.1016/j.fertnstert.2007.03.037)

Zaman K, Roy E, Arifeen SE, Rahman M, Raqib R, Wilson E, Omer SB, Shahid NS, Breiman RF \& Steinhoff MC 2008 Effectiveness of maternal influenza immunization in mothers and infants. New England Journal of Medicine 359 1555-1564. (doi:10.1056/NEJMoa0708630)
Zeldovich VB, Robbins JR, Kapidzic M, Lauer P \& Bakardjiev AI 2011 Invasive extravillous trophoblasts restrict intracellular growth and spread of Listeria monocytogenes. PLoS Pathogens 7 e1002005. (doi:10.1371/ journal.ppat.1002005)

Zheng Y, Josefowicz S, Chaudhry A, Peng XP, Forbush K \& Rudensky AY 2010 Role of conserved non-coding DNA elements in the Foxp3 gene in regulatory T-cell fate. Nature 463 808-812. (doi:10.1038/nature 08750)

Zuckermann FA \& Head JR 1986 Expression of MHC antigens on murine trophoblast and their modulation by interferon. Journal of Immunology 137 846-853.

Received 17 June 2013

First decision 11 July 2013

Revised manuscript received 30 July 2013

Accepted 8 August 2013 